Acta vet. scand. 1988, 29, 193-198.

From the National Veterinary Institute, Oslo,

Department of Microbiology and Immunology, Norwegian College of Veterinary Medicine, Oslo, Institute of Transplantation Immunology, National Hospital, Oslo,

Department of Animal Husbandry and Genetics, Norwegian College of Veterinary Medicine, Oslo, and Institute of Animal Breeding, Division of Immunogenetics,

Veterinary School of University of Berne, Switzerland.

\title{
A Human Major Histocompatibility Complex (MHC) DNA Probe Recognizes Goat Genes
}

\author{
By L. L. Nesse, G. Paulsen, M. Syed and G. Ruff
}

\begin{abstract}
Nesse, L. L., G. Paulsen, M. Syed and G. Ruff: A human major histocompatibility complex (MHC) DNA probe recognizes goat genes. Acta vet. scand. 1988, 29, 193-198. - A human major histocompatibility complex (MHC) class II (DR- $\beta$ ) probe was hybridized with restriction enzyme digest of genomic DNA from 14 goats. Nine of the animals belonged to one family. Digestion of the DNA with the restriction enzyme Eco RI gave 7 fragments in 13 animals and 6 fragments in the last animal. No other polymorphism could be detected. Bam HI digestion gave from 3 to 6 fragments which displayed a considerable polymorphism. In the family studied, polymorphic fragments were inherited together with serologically defined lymphocyte antigen specificities believed to be coded for by MHC class I genes.

lymphocyte antigens; restriction fragment length polymorphism; RFLP; tissue typing; tissue antigens.
\end{abstract}

\section{Introduction}

In order to mount an immune response, the cells of the immune system communicate via certain special molecules on their surface membranes. An important group of such molecules is comprised by the so-called "major histocompatibility antigens". They are divided into class I and II according to certain differences in structure and function. The genes coding for these antigens are clustered together in an area called the major histocompatibility complex (MHC). There is a large number of alternative MHC genes of both class I and II. Due to this polymorphism, the combination of MHC antigens varies from individual to individual.

MHC is especially interesting because several diseases, both in humans and animals, have been shown to have a statistically sign- ificant association with certain MHC antigens. This means that the risk of developing certain diseases is higher in individuals with certain MHC antigens. In humans, this knowledge has mostly been used for diagnostic purposes and studies of disease mechanisms. In animals, it is possible to consider such information being used for early identification and exclusion of "high risk" animals in breeding programmes.

Most of the information about the MHC has resulted from studies on humans and mice. Investigations on several animal species indicate that they all have a similar MHC. However, relatively little information is available on the goat MHC. Studies by van Dam et al. (1979) gave reason to believe that the goat MHC contained both class I and II genes. Lymphocyte antigen specificities be- 
lieved to be HMC class I antigens have been serologically characterized in Norwegian dairy goats (Nesse \& Larsen 1985) and in seven different Swiss goat breeds $(R u f f \& L a$ zary 1985).

Until recently, in no species had polymorphism of the MHC been studied on other than the gene products, i.e. the surface molecules. Modern biotechnology has now made it possible to study the MHC-genes themselves, using DNA-probes and the technique of restriction fragment length polymorphism (RFLP). So far, most MHC probes have been generated from human or mouse DNA, though experiments have shown cross-hybridization between human MHC probes and DNA from other species such as cattle, pigs, horses and sheep (Andersson et al. 1986, Vaiman et al. 1986). In humans, stronger associations between MHC and certain diseases have been found by means of the RFLP technique (Cohen-Haguenauer et al. 1985).

The aims of the present study were to test whether: 1) a human MHC class II probe could cross-hybridize with genomic DNA from goats; 2) the probe could be used to study polymorphism of the goat genes; 3 ) such a polymorphism was inherited together with the serologically defined lymphocyte antigens which are believed to be encoded by the goat MHC class I genes.

\section{Material and methods}

DNA sources

Goat DNA was isolated from leucocytes from 14 animals, of which 9 belonged to one family of Norwegian Dairy goats. The other 5 animals were unrelated. Two of them were Norwegian Dairy goats, and 3 were Swiss Toggenburger goats. Human DNA was isolated from 3 human Epstein-Barr-virustransformed B-cell lines, which were homozygous for the MHC class II specificites DR
3 (LHM), DR 4 (JAH) (origin: Dr. J. H. Hansen, Seattle, USA) and DR 8 (MMR, origin: Dr. A. Termijtelen, Leiden, West Germany), respectively.

DNA isolation and RFLP procedure

DNA isolation from leucocytes, electrophoresis, DNA Southern blotting (Southern 1975), prehybridization and hybridization was performed as described by Paulsen et al. (1987).

Before electrophoresis, samples of $10 \mu \mathrm{g}$ DNA were digested with the restriction enzymes Eco RI or Bam HI (25 units) overnight at $37^{\circ} \mathrm{C}$ in the buffers recommended by the manufacturer (Amersham, England). Hind III digested lambda-DNA was used as a fragment length marker. Hybond $\mathrm{N}$ (Amersham) was used as blotting membranes. The probe was a denaturated "nicktranslated" class II DR-beta cDNA probe (pII-ß4) (Gustavsson et al. 1984) which was isolated from the plasmid vector as described elsewhere (Paulsen et al. 1987). The hybridised membranes were washed $3 \times 5 \mathrm{~min}$ in $2 \times$ SSPE (SSPE: $0.01 \mathrm{~mol} / 1 \mathrm{NaH}_{2} \mathrm{PO}_{4}$, $0.18 \mathrm{~mol} / 1 \mathrm{NaCl}, 0.001 \mathrm{~mol} / 1 \mathrm{EDTA}, \mathrm{pH}$ 7.4) at room temperature, and $2 \times 20 \mathrm{~min}$ in $0.2 \times \mathrm{SSPE} / 0.2 \% \mathrm{SDS}$ at $65^{\circ} \mathrm{C}$. Autoradiography was performed at $-70^{\circ} \mathrm{C}$ using intensifying screens.

\section{MHC class I antigens in the goats}

MHC class I antigens of the goats were serologically determined, as described earlier (Nesse \& Larsen 1987, Ruff 1987). The designations of the specificities consist of a number and a prefix which is "N" for specificities only found in Norway and "Eu" for those found both in Norway and Switzerland (Nesse et al. 1987). The genes coding for these antigens belong to 2 closely linked loci. 
Table 1. Pedigree of the goat family studied.

\begin{tabular}{|c|c|c|c|c|}
\hline Parents & $\begin{array}{l}\text { Haplot } \\
\text { first }\end{array}$ & $\begin{array}{l}\text { ypes: } \\
\text { / second }\end{array}$ & Kids & $\begin{array}{l}\text { Haplotypes from: } \\
\text { mother / father }\end{array}$ \\
\hline Sire & Eu6 & / Eu4, Eu9 & & \\
\hline Dam 1 & Eu2 & / Eu9, Eu13 & $\begin{array}{l}\text { Kid } 1 \\
\text { Kid } 2\end{array}$ & $\begin{array}{l}\text { Eu2 / Eu4, Eu9 } \\
\text { Eu2 / Eu4, Eu9 }\end{array}$ \\
\hline Dam 2 & Eu12 & / Eu6 & $\begin{array}{l}\text { Kid } 3 \\
\text { Kid } 4\end{array}$ & $\begin{array}{l}\text { Eu12 / Eu4, Eu9 } \\
\text { Eu12 / Eu6 }\end{array}$ \\
\hline Dam 3 & N2 & / Eu2 & $\begin{array}{l}\text { Kid } 5 \\
\text { Kid } 6\end{array}$ & $\begin{array}{ll}\text { N2 } & / \text { Eu6 } \\
\text { N2 } & / \text { Eu6 }\end{array}$ \\
\hline
\end{tabular}

Family studies

Family studies were performed on a family consisting of 1 sire, 3 dams and their 6 offspring (Table 1). The sire had the 2 haplotypes Eu6 and Eu4, Eu9, of which 3 kids had inherited the haplotype Eu4, Eu9 and the 3 others had inherited Eu6.

\section{Results}

The human MHC DR- $\beta$ probe cross-hybridized with genomic DNA from goats. When

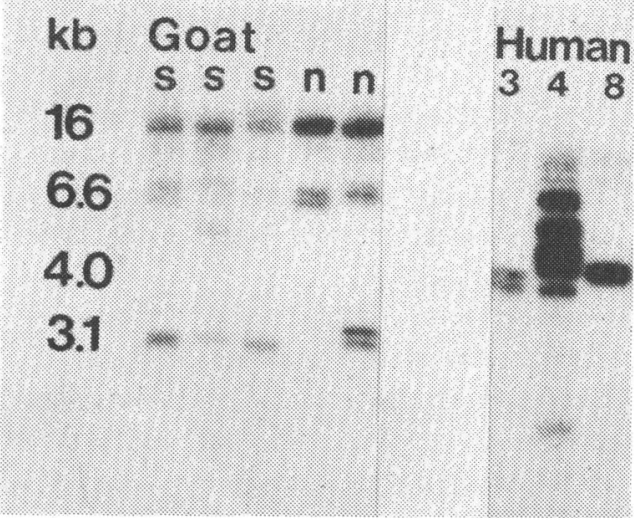

Figure 1. Restriction fragment length polymorphism of Bam HI-digested DNA from 3 Swiss goats (s), 2 Norwegian goats (n) and 3 different human cell lines. The numbers on the human cell lines show their class II- (DR-) specificities. All the DNA samples were located on the same membrane, and were at all stages of the procedure treated exactly the same way. human and goat DNA were located on the same membrane and treated in the same way, the human DNA seemed to give the strongest hybridization signals (Fig. 1).

\section{Eco RI digestion of goat DNA}

In goat DNA digested with Eco RI, 7 fragments (range 9.4-2.7 kb) could be detected in all the animals, except for one (kid 21) which lacked the $2.7 \mathrm{~kb}$-fragment. No other restriction fragment length polymorphism was detected.

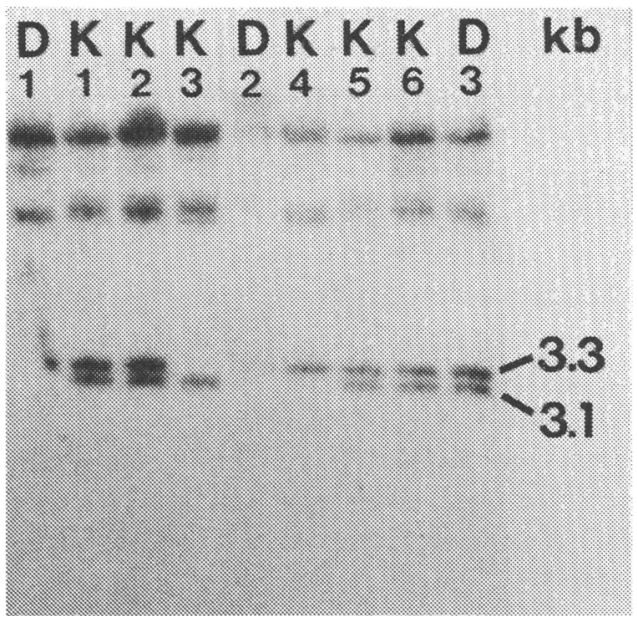

Figure 2. Restriction fragment length polymorphism of Bam HI-digested DNA from the goat family tested $(D=$ dam, $K=$ kid). The restriction fragment patterns of dams 1 and 2 were confirmed in another autoradiogram (not shown). 
Table 2. Suggested inheritance of the fragments "A" and "B" together with the serologically defined MHC class I antigens.

\begin{tabular}{|c|c|c|c|c|}
\hline \multirow[t]{2}{*}{ Parents } & \multirow{2}{*}{$\begin{array}{c}\text { Fragment } \\
3.1 \mathrm{~kb} \\
=\mathrm{A}\end{array}$} & \multirow{2}{*}{$\begin{array}{c}\text { Fragment } \\
3.3 \mathrm{~kb} \\
=\mathrm{B}\end{array}$} & \multicolumn{2}{|l|}{ Suggested haplotypes: } \\
\hline & & & / second & \\
\hline Sire & $\left.\mathrm{NT}^{*}\right)$ & NT & Eu6, B / Eu4, Eu9, & A \\
\hline Dam 1 & - & + & Eu2, B / Eu9, Eu13, & \\
\hline Dam 2 & - & + & Eu12, / Eu6, & B \\
\hline Dam 3 & + & + & N2, A / Eu2, & B \\
\hline \multirow[t]{2}{*}{ Kids } & \multirow{2}{*}{$\begin{array}{c}\text { Fragment } \\
3.1 \mathrm{~kb} \\
=\mathrm{A}\end{array}$} & \multirow{2}{*}{$\begin{array}{c}\text { Fragment } \\
3.3 \mathrm{~kb} \\
=\mathrm{B}\end{array}$} & \multicolumn{2}{|l|}{ Suggested haplotypes: } \\
\hline & & & from dam / from sire & \\
\hline Kid 1 & + & + & Eu2, B / Eu4, Eu9, & A \\
\hline Kid 2 & + & + & Eu2, B / Eu4, Eu9, & A \\
\hline Kid 3 & + & - & Eu12, / Eu4, Eu9, & A \\
\hline Kid 4 & - & + & Eu12, / Eu6, & B \\
\hline Kid 5 & + & + & N2, A / Eu6, & B \\
\hline Kid 6 & + & + & N2, A / Eu6, & B \\
\hline
\end{tabular}

*) NT = not tested.

\section{Bam HI digestion of goat DNA}

Digestion with BAM HI gave from 3 to 6 detectable fragments per genome. One of these fragments $(16 \mathrm{~kb})$ was observed in all the animals. The location of the remaining fragments (range 9.4-3.1 kb) showed variation between animals (Figs. 1 and 2).

\section{Family studies}

The restriction fragment patterns revealed by Bam HI digestion were used in the family studies (Fig. 2, Table 2). One fragment (3.1 $\mathrm{kb})$, here called A, was found in all the kids that had inherited the haplotype Eu4, Eu9 from the sire. One other fragment $(3.3 \mathrm{~kb})$, here called B, was found in all the kids that had inherited the sire's other haplotype (Eu6). When considering the fragments found in the dams, the other A- and Bfragments found in the kids, and the haplotypes inherited by the kids from the dams, it could clearly be seen that the fragment A was inherited together with the sire's haplotype Eu4, Eu9. The fragment B seemed to be inherited together with the other haplotype (Eu6) of the sire, provided that no recombination had occurred. The remaining polymorphic fragments were not considered distinct enough to allow firm conclusions as to how they were inherited.

\section{Discussion}

In the present study, a human MHC class II probe (DR- $\beta$ ) was successfully cross-hybridized with goat DNA. Similar probes have earlier been shown to cross-hybridize with DNA from cattle, pigs, sheep and horses (Andersson et al. 1986, Vaiman et al. 1986). However, the number of fragments detected in Eco RI digested DNA was reported to be higher in these animals than in the goats in the present study. Vaiman et al. reported 15-16 fragments in pigs, $10-11$ in sheep, 9-10 in cattle and 15-20 in horses. In the 
goats, only 7 fragments were detected with this enzyme. The samples from pigs, sheep, cattle and horses were reported to have been tested under adapted stringency conditions for each species. Vaiman et al. suggested that some of the weak hybridization signals they found were due to cross-hybridization with other class II genes, for example DQ$\beta$-like genes. The goat samples were treated in the same way as human DNA. If they had been washed under conditions of adapted stringency, a more complicated restriction pattern might also have been obtained in the goat DNA. Possible cross-reacting DQ- $\beta$ like fragments are the ones most likely to have been dehybridized as a result of the more stringent washing procedure, thus giving a more "clear cut" pattern of the DR- $\beta$ gene. However, one cannot exclude the possibility that also DR- $\beta$-like fragments may have been "lost".

These experiments showed that a human MHC class II probe may be used to study polymorphism of goat genes. Although the family studies included only a small number of animals, and the results may therefore have been influenced both by chance and by the occurrence of recombinations, they strongly indicated that polymorphic fragments were inherited together with class I MHC antigens. This means that human MHC probes most likely recognize MHC genes also in the goat, and may hence be valuable tools in future research on the MHC of this species.

\section{References}

Andersson L, Böhme J, Rask L, Peterson PA: Genomic hybridization of bovine class II histocompatibility genes: 1 . Extensive polymorphism of DQ- $\alpha$ and DQ- $\beta$ genes. Anim. Genet. 1986, 7, 95-112.

Cohen-Haguenauer $O$, Robbins E, Massart C, Busson M, Deschamps I, Hors J, Lalouel JM,
Dausset J, Cohen D: A systematic study of HLA class II- $\beta$ DNA restriction fragments in insulin-dependet diabetes mellitus. Proc. Natl. Acad. Sci. 1985, 80, 6289-6292.

van Dam RH, D'Amaro J, van Kooten PJS, van der Donk JA, Goudswaard J: The histocompatibility complex GLA in the goat. Anim. Blood Grps. Biochem. Genet. 1979, 10, 121123.

Gustafsson K, Wiman K, Emmoth E, Larhammar D, Böhme J, Hyldig-Nielsen JJ, Ronne H, Peterson PA, Rask L: Mutations and selection in the generation of class II histocompatibility antigen polymorphism. EMBO J., 1984, 3, 1655-1661.

Nesse LL, Larsen HJ: Caprine lymphocyte antigens - Serological and genetic studies. Anim. Blood Grps. Biochem. Genet. 1985, 16 (Supplement 1), 123-124.

Nesse LL, Larsen HJ: Lymphocyte antigens in Norwegian goats: Serological and genetic studies. Anim. Genet. 1987, 18, 261-268.

Nesse LL, Ruff G, Larsen HJ, Lazary S: Caprine lymphocyte antigens: A comparison between Norway and Switzerland. Anim. Genet. 1987, 18 (Supplement 1), 32-33.

Paulsen G, Markussen G, Sollid L, Thorsby E: Determination of the HLA DR profile of a HLA class II negative carcinoma cell line by restriction fragment length polymorphism (RFLP) analysis. Tissue Antigens, 1987, 29, 186-194.

Ruff $G$, Lazary $S$ : Investigations on the goat leucocyte antigen (GLA) system. Anim. Blood Grps. Biochem. Genet. 1985, 16 (Supplement 1), 123.

Ruff $G$ : Investigations on the caprine leucocyte antigen (CLA) system. Thesis, Bern, 1987.

Southern EM: Detection of specific sequences among DNA fragments separated by gel electrophoresis. J. Molecular Biol. 1975, 98, 503517.

Vaiman $M$, Chardon P, Cohen D: DNA polymorphism in the major histocompatibility complex of man and various farm animals. Anim. Genet. 1986, 17, 113-131. 


\section{Sammendrag}

En human vevstype DNA probe gjenkjenner gener hos geit.

DNA fra 14 geiter ble fordøyet med to forskjellige restriksjonsenzymer og deretter hybridisert med en human vevstypeprobe av klasse II (DR- $\beta$ ). $\mathrm{Ni}$ av geitene tilhørte samme familie. Etter bruk av restriksjonsenzymet Eco RI, bandt proben seg til 7 DNA-fragmenter av forskjellig størrelse hos 13 av geitene og til 6 fragmenter hos det siste dyret. "Fragmentmønsteret" var likt hos alle dyrene, bortsett fra hos det siste som manglet det minste fragmentet. Det kunne således bare påvises en liten grad av polymorfisme ved hjelp av dette enzymet. Ved bruk av enzymet Bam HI ble det derimot observert store forskjeller fra dyr til dyr. Proben bandt seg til 3-6 fragmenter av varierende størrelse, og ga dermed varierende "fragmentmønstre" fra dyr til dyr. I den undersøkte familien så det ut til at mønstrene ble nedarvet sammen med serologisk påvisbare lympfocyttantigener som man mener er vevstyper av klasse I. Undersøkelsen viser at humane prober kan være verdifulle redskaper ved studier av vevstypekomplekset hos geit.

(Received November 24, 1987).

Reprints may be requested from: L. L. Nesse, National Veterinary Institute, P. O. Box 8156 Dep., N-0033 Oslo 1, Norway. 